\title{
Assessing the Risk of Hg Exposure Associated with Rice Consumption in a Typical City (Suzhou) in Eastern China
}

\author{
Gang Wang ${ }^{1}$, Yu Gong ${ }^{1}$, Yi-Xin Zhu ${ }^{2}$, Ai-Jun Miao ${ }^{1}$, Liu-Yan Yang ${ }^{1, *}$ and Huan Zhong ${ }^{1, *}$ \\ 1 State Key Laboratory of Pollution Control and Resource Reuse, School of the Environment, Nanjing \\ University, Nanjing 210023, China; gwang@189.cn (G.W.); gongyu111@hotmail.com (Y.G.); \\ miaoaj@nju.edu.cn (A.-J.M.) \\ 2 CQC Intime Testing Technology Co. Ltd., Suzhou 210023, China; cqc_zhuyx@126.com \\ * Correspondence: yangly@nju.edu.cn (L.-Y.Y.); zhonghuan@nju.edu.cn (H.Z.); Tel.: +86-25-8968-0316 (H.Z.)
}

Academic Editor: Sayed M. Hassan

Received: 10 April 2017; Accepted: 10 May 2017; Published: 12 May 2017

\begin{abstract}
Recent studies have revealed that not only fish but also rice consumption may significantly contribute to human exposure to mercury $(\mathrm{Hg})$ in Asian countries. It is therefore essential to assess dietary exposure to $\mathrm{Hg}$ in rice and its associated health risk. However, risk assessments of $\mathrm{Hg}$ in rice in non-contaminated areas are generally lacking in Asian countries. In the present study, $\mathrm{Hg}$ concentrations were measured in rice samples collected from markets and supermarkets in Suzhou, a typical city in Eastern China. In addition, the rice ingestion rates (IR) were assessed via a questionnaire-based survey of Suzhou residents. The data were then used to assess the risk of $\mathrm{Hg}$ exposure associated with rice consumption, by calculating the hazard quotient $(\mathrm{HQ})$. $\mathrm{Hg}$ contents in rice samples were well below the national standard $(20 \mu \mathrm{g} / \mathrm{kg})$, ranging from 1.46 to $8.48 \mathrm{ng} / \mathrm{g}$. They were also significantly $(p>0.05)$ independent of the area of production and place of purchase (markets vs. supermarkets in the different districts). Our results indicate a low risk of $\mathrm{Hg}$ exposure from rice in Suzhou (HQ: 0.005-0.05), despite the generally high personal IR (0.05-0.4 kg/day). The risk of $\mathrm{Hg}$ associated with rice consumption for Suzhou residents was not significantly affected by the age or sex of the consumer $(p>0.05)$. Overall, our results provide a study of human exposure to $\mathrm{Hg}$ in rice in Chinese cities not known to be contaminated with Hg. Future studies should examine $\mathrm{Hg}$ exposure in different areas in China and in potentially vulnerable major food types.
\end{abstract}

Keywords: mercury; rice; food safety; dietary exposure

\section{Introduction}

Since the recognition of Minamata disease in 1956, mercury (Hg)-related food safety issues have been a matter of concern throughout the world, but especially in Asia. It is generally believed that fish/shellfish consumption is one of the major route of human exposure to $\mathrm{Hg}$ [1-5]. A significantly positive correlation $(\mathrm{R}=0.401, p<0.001, n=174$ ) was found between the consumption of fish and total $\mathrm{Hg}$ in the respondents [6]. Therefore, $\mathrm{Hg}$ contents in fish/shellfish and the associated health risk to consumers have been extensively studied [7-9]. Detrimental effects of $\mathrm{Hg}$ associated with fish/shellfish consumption have thus been reported in a number of studies, e.g., the European fish-eating cohorts under Public Health Impact of Low-level Mixed Element Exposure (PHIME), the Seychelles Child Development Study, and the New Zealand fish-eating cohort [10-12]. Recent studies indicate that rice consumption could also contribute significantly to human exposure to $\mathrm{Hg}[13,14]$. In certain inland areas of China (e.g., Wanshan mining area), rice consumption was found to be responsible for the majority of human $\mathrm{Hg}$ exposure (as high as $42 \%$ ) [15], due to the high consumption rates (600 g/day) 
of rice containing high $\mathrm{Hg}$ contents. The flooding conditions of rice paddies could facilitate $\mathrm{Hg}$ transformation to the highly bioaccumulative species methylmercury $(\mathrm{MeHg})$, which accumulates in rice grains at elevated contents [16]. Zhang reported that $\mathrm{MeHg}$ has a bioconcentration factor which is on average $>800$ times higher than that of inorganic $\mathrm{Hg}$ ( 0.71 to 50 vs. 0.0014 to 0.51 ) [13]. Therefore, assessments of the risk of $\mathrm{Hg}$ exposure associated with rice consumption in Asian countries, where rice is the staple food for the majority of the respective populations, is essential.

In the last decade, the exposure of Asian populations to $\mathrm{Hg}$ in rice has been investigated in several studies, many of which focused on consumers in China [7-9,13,14]. In Guizhou Province, China, an area of intensive $\mathrm{Hg}$ mining, food (especially rice) rather than inhalation was shown to be the major route of human exposure to $\mathrm{Hg}$. It is reported that food consumption accounts for more than $90 \%$ of the probable daily intake (PDI) of Total Hg. Specifically, rice accounted for $18.6-25.5 \%$, while inhalation accounted for 3.8-6.8\% [17], not to mention that rice can accumulate $\mathrm{Hg}$ from both atmosphere and soil [18]. In the same $\mathrm{Hg}$ mining region, $\mathrm{MeHg}$ levels in hair were shown to well correlate with dietary exposure to $\mathrm{MeHg}$ in rice, which could be explained by the overwhelming contribution of the rice consumption [19]. Those pioneering studies provided important insights into the risk associated with rice consumption in Asian populations and the need for comprehensive studies. However, most studies carried out thus far investigated $\mathrm{Hg}$-contaminated areas, e.g., $\mathrm{Hg}$ mining areas, whereas little is known about exposure to rice $\mathrm{Hg}$ by the general population of China and of other Asian countries. This deficit of data may hinder accurate assessments of dietary exposure to $\mathrm{Hg}$ and the associated health risk; but these studies are important given that chronic exposure to low levels of $\mathrm{Hg}$ can induce nervous system dysfunction as well as renal, reproductive, immune, and cardiovascular damage and that the population of the non-contaminated area is much larger than its counterpart in Hg-contaminated areas [20,21]. Based on limited study, it has been found that most of the rice-consumption-related exposure of $\mathrm{Hg}$ is far below the Provisional Tolerable Weekly Intake (PTWI), as established by World Health Organization (WHO) in 1972 and adjusted by Joint Expert Committee on Food Additives (JECFA) from Food and Agriculture Organization (FAO)/WHO in 2010. Whether this finding can be extended to other areas needs to be further examined.

The aim of the present study is to evaluate the potential risk of $\mathrm{Hg}$ associated with rice consumption in a typical city in eastern China. Suzhou (Jiangsu Province) was selected principally because: (1) It is far away from $\mathrm{Hg}$ mining areas with its industry mainly made up of information technology, equipment manufacturing, textiles, tourism and is thus a representative of non-contaminated cities in China; (2) Suzhou has the second largest population and second highest gross domestic product (GDP) among cities in eastern China right after Shanghai.; (3) The rice ingestion rates (IRs) for consumers in Suzhou lie between those of consumers in northern China, where wheat is the main food, and those in southern China, where rice is the staple food [22]. Rice samples were collected from local markets and supermarkets in Suzhou and their $\mathrm{Hg}$ contents were quantified. In addition, a questionnaire-based survey was conducted to assess the IRs of consumers in Suzhou. The risk of $\mathrm{Hg}$ ingestion associated with rice consumption in city residents was then assessed by calculating the hazard quotient (HQ). Our results contribute to a better understanding of the risk of $\mathrm{Hg}$ for the general populations of Asian cities.

\section{Materials and Methods}

\subsection{Sampling and Hg Analysis}

Suzhou city, one of the major cities in Jiangsu Province, locates in the center of Yangtze River Delta. It is between $30^{\circ} 02^{\prime}-32^{\circ} 02^{\prime} \mathrm{E}$ and $119^{\circ} 55^{\prime}-121^{\circ} 20^{\prime} \mathrm{N}$, bordering on Jiaxing and Huzhou of Zhejiang Province on the south, and Shanghai on the east. According to our preliminary survey, the major sources of rice for consumers in Suzhou are markets and supermarkets, which are primarily produced in northeastern China (NEC) and northern Jiangsu (NJS). Thus, the 177 rice samples analyzed in the present study were collected from local markets (3-27 per district) and supermarkets (2-7 per 
district) in Suzhou in November, 2016 (Figure 1). The locations of rice productions were recorded when collecting the rice samples (i.e., as NEC or NJS rice).

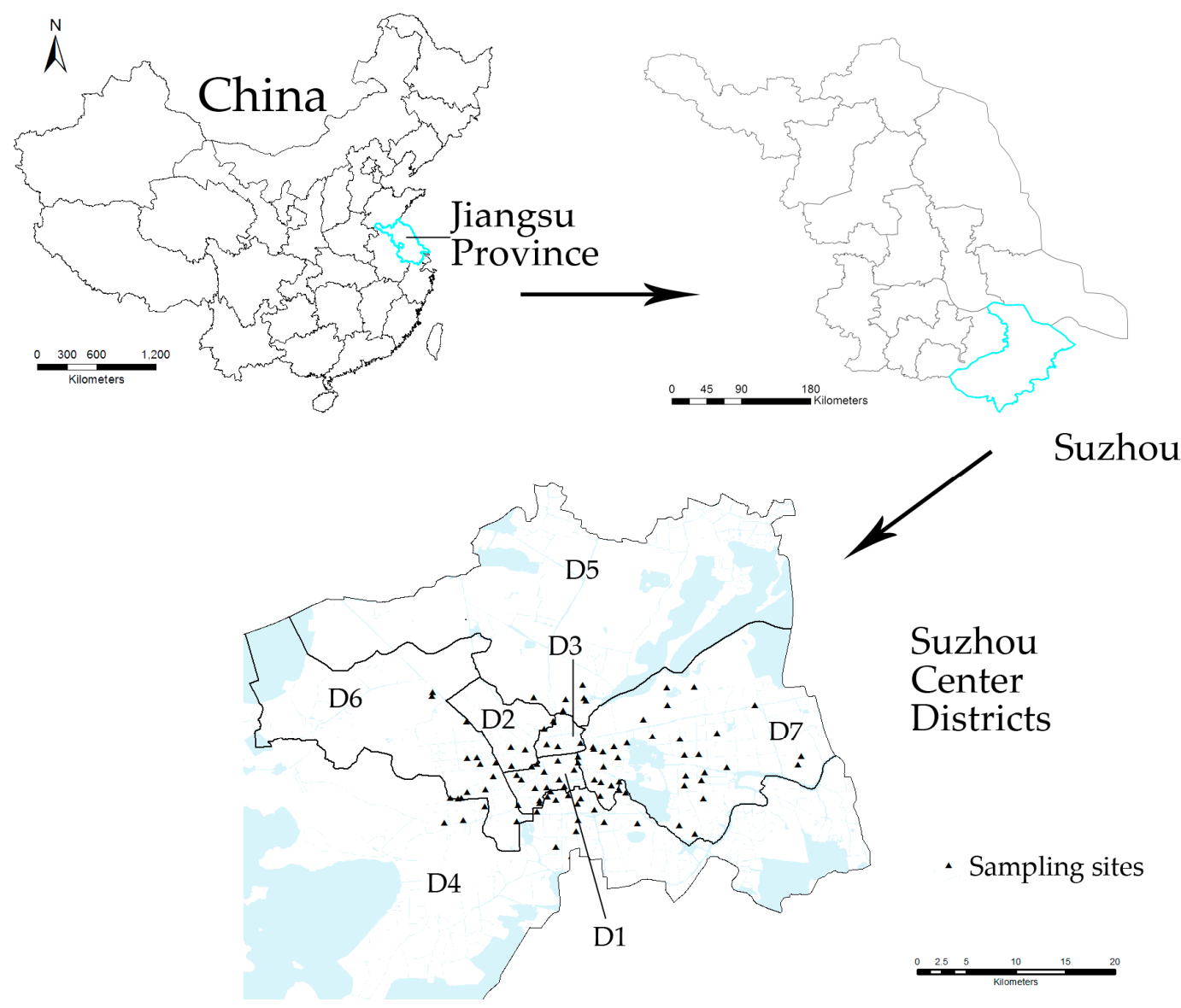

Figure 1. Sampling sites in Suzhou Center Districts, Jiangsu, China. D1: Canglang District, D2: Jingchang District, D3: Pingjiang District, D4: Wuzhong District, D5: Xiangcheng District, D6: Huqiu District, D7: Suzhou Industrial Park District.

All rice samples were washed, freeze-dried, ground into powders, and sieved through 100- $\mu \mathrm{m}$ meshes. Considering the processing capacity (no more than $500 \mathrm{mg}$ ) of the instrument and its $\mathrm{Hg}$ detection limit of $0.2 \mathrm{ng} / \mathrm{g}, 100-180 \mathrm{mg}$ rice powder was weighed in triplicates from each sample and their Hg contents measured using a DMA-80 (Milestone Inc., Sorisole, Italy) direct Hg analyzer, based on United States Environmental Protection Agency(USEPA) Method 7473 (1998). Certified reference material (GBW10043) with a total $\mathrm{Hg}$ content of $4.8 \pm 0.8 \mathrm{ng} / \mathrm{g}$ and instrument blanks were used for quality control. The recoveries of $\mathrm{Hg}$ in the certified reference material ranged from $112 \%$ to $119 \%$.

\subsection{Questionnaire Survey}

A questionnaire survey of randomly selected participants in different districts was conducted in November 2016. The questions in the questionnaire included: (1) the amount of rice consumed per meal (g/meal); (2) the frequency of rice consumption (meals/week); (3) the major source of rice purchase; and (4) personal information (sex, age and body weight). Of the 295 questionnaires distributed, 236 were completed and collected. 


\subsection{Health Risk Assessment}

As there are not enough data to demonstrate the carcinogenicity of $\mathrm{Hg}$ [23], we use a method provided by USEPA to evaluate the potential health risk for non-carcinogenic effects of Hg exposure [24].

In this method, dietary $\mathrm{Hg}$ exposure through rice intake was indicated as the estimated daily intake (EDI, ng/kg body weight/day):

$$
\mathrm{EDI}=\frac{\mathrm{C} \times \mathrm{IR}}{\mathrm{BW}}
$$

where $\mathrm{C}$ is the $\mathrm{Hg}$ content $(\mathrm{ng} / \mathrm{g})$ in rice, IR is the rice ingestion rate $(\mathrm{g} / \mathrm{d})$, and BW is body weight, measured in $\mathrm{kg}$.

The non-carcinogenic health risk HQ was used to assess the potential health risk of $\mathrm{Hg}$ as follows:

$$
\mathrm{HQ}=\frac{\mathrm{EDI} \times 7}{\mathrm{PTWI}}
$$

where PTWI is the provisional tolerable weekly intake of $\mathrm{Hg}$, which was adjusted from $5.0 \mu \mathrm{g} / \mathrm{kg}$ $\mathrm{BW} /$ week to $4.0 \mu \mathrm{g} / \mathrm{kg} \mathrm{BW} /$ week by JECFA. A HQ value $>1$ indicates a potential health risk due to $\mathrm{Hg}$ exposure from rice consumption.

\subsection{Statistical Analysis}

Significant differences $(p<0.05)$ were determined based on the results of a one-way analysis of variance (ANOVA) with post-hoc multiple comparisons (Tukey or Tamhane) (SPSS 11.0 by SPSS, Chicago, IL, USA). The normality (Kolmogorov-Smirnov and Shapiro-Wilk tests) and homogeneity of variance (Levene's test) of the data were examined during the ANOVAs.

\section{Results and Discussion}

\subsection{Mercury Contents in Rice in Suzhou City}

The $\mathrm{Hg}$ contents of the rice samples from the different sources are listed in Table 1 . They ranged from 1.46 to $8.48 \mathrm{ng} / \mathrm{g}$ (mean $3.83 \mathrm{ng} / \mathrm{g}$ ). They were thus consistently lower than the national standard of $20 \mu \mathrm{g} / \mathrm{kg}$ (GB 2762-2012, China national food safety standard: Maximum limit of contaminants in food) [25] and within the ranges reported in non-contaminated areas of China. For example, in Zhejiang Province, Hg contents in rice were $5 \mathrm{ng} / \mathrm{g} \pm 3 \mathrm{ng} / \mathrm{g}$ [14], in Jiangsu Province 5.7 ng/g [15], and in Chongqing city 1.9-4.2 ng/g [16]. As for the rice samples in other countries, their $\mathrm{Hg}$ content was $3.04 \mathrm{ng} / \mathrm{g} \pm 2.07 \mathrm{ng} / \mathrm{g}$ in Europe [26] and $2.91 \mathrm{ng} / \mathrm{g} \pm 0.86 \mathrm{ng} / \mathrm{g}$ in Republic of Korea [27]. These data imply that $\mathrm{Hg}$ contents in non-contaminated areas around the world are at the same order of magnitude.

When comparing the rice from different sources, $\mathrm{Hg}$ levels in rice from northeastern China (NEC: $1.67-8.31 \mathrm{ng} / \mathrm{g}$, averagely $3.61 \mathrm{ng} / \mathrm{g}$ ) and from northern Jiangsu (NJS) (1.46-8.48 ng/g, averagely 4.04 $\mathrm{ng} / \mathrm{g}$; Figure 2a) were comparable $(p>0.05)$ to each other. This finding is consistent with the generally low $\mathrm{Hg}$ contents in NEC and NJS soils: The average content of $\mathrm{Hg}$ in NJS topsoil is $0.1 \mathrm{mg} / \mathrm{kg}$, and it is even lower for the soils of NEC, e.g., $0.064 \mathrm{mg} / \mathrm{kg}$ in Liaoning Province [28], $0.031 \mathrm{mg} / \mathrm{kg}$ in Heilongiiang Province [29], and $0.04 \mathrm{mg} / \mathrm{kg}$ for Jilin Province [30]. These values are much lower than the values stated in the national guideline for farmland $(0.25 \mathrm{mg} / \mathrm{kg}$ when soil $\mathrm{pH} \leq 5.5,0.35 \mathrm{mg} / \mathrm{kg}$ when $5.5<\mathrm{pH} \leq 6.5,0.70 \mathrm{mk} / \mathrm{kg}$ when $6.5<\mathrm{pH} \leq 7.5,1.5 \mathrm{mg} / \mathrm{kg}$ when $\mathrm{pH}>7.5$, Environmental quality standards for soils, Ministry of Environmental Protection of China, GB 15618-2008) [31]. By contrast, the $\mathrm{Hg}$ content $(11 \mathrm{mg} / \mathrm{kg} \pm 1.9 \mathrm{mg} / \mathrm{kg}$ ) in soils from Gouxi, Guizhou Province, was much higher than the national standard and thus the $\mathrm{Hg}$ content in the rice from these areas was in the range of $120 \mathrm{ng} / \mathrm{g} \pm 33 \mathrm{ng} / \mathrm{g}$ with MeHg being the major $\mathrm{Hg}$ species [32]. Moreover, $\mathrm{Hg}$ levels were comparable in rice purchased from markets $(1.64-8.48 \mathrm{ng} / \mathrm{g}$, average $3.87 \mathrm{ng} / \mathrm{g})$ and supermarkets 
(1.46-6.48 ng/g, average $3.66 \mathrm{ng} / \mathrm{g}$; Figure $2 \mathrm{~b}$ ), because the sources of the rice were probably the same or similar (NEC and NJS). Thus, at least in Suzhou, where the rice was purchased (in markets or supermarkets), the sources of the rice sold in the city did not differ in their contributions to the risk of $\mathrm{Hg}$ exposure associated with rice consumption. Nevertheless, this may not be always the case in other non-contaminated areas.

Table 1. Hg content in rice of different sources (NEC: northeastern China; NJS: northern Jiangsu) from different districts of Suzhou city.

\begin{tabular}{|c|c|c|c|c|c|c|c|c|c|}
\hline District & $\begin{array}{l}\text { Sampling } \\
\text { Site } \\
\text { Number }\end{array}$ & $\begin{array}{l}\text { NEC } \\
\text { (ng/g) }\end{array}$ & $\begin{array}{l}\text { NJS } \\
\text { (ng/g) }\end{array}$ & $\begin{array}{l}\text { Sampling } \\
\text { Site } \\
\text { Number }\end{array}$ & $\begin{array}{l}\text { NEC } \\
\text { (ng/g) }\end{array}$ & $\begin{array}{l}\text { NJS } \\
\text { (ng/g) }\end{array}$ & $\begin{array}{l}\text { Sampling } \\
\text { Site } \\
\text { Number }\end{array}$ & $\begin{array}{l}\text { NEC } \\
\text { (ng/g) }\end{array}$ & $\begin{array}{l}\text { NJS } \\
(\mathrm{ng} / \mathrm{g})\end{array}$ \\
\hline \multirow{4}{*}{$\begin{array}{l}\text { D1 (Canglang } \\
\text { District) }\end{array}$} & S16 & 3.03 & 1.67 & S19 & 1.94 & 2.81 & $\mathrm{~S} 22$ & 3.3 & N.A. \\
\hline & $\mathrm{S} 23$ & 4.08 & 5.26 & S24 & 4.7 & N.A. & S30 & 3.28 & 3.41 \\
\hline & S31 & 2.71 & N.A. & S38 & 4.03 & N.A. & S41 & 2.51 & 4.81 \\
\hline & S51 & 2.54 & 1.86 & & & & & & \\
\hline \multirow{2}{*}{$\begin{array}{c}\mathrm{D} 2 \\
\text { (Jinchang District) }\end{array}$} & S10 & 3.34 & 3.22 & S11 & 8.31 & 3.65 & S17 & N.A. & 3.41 \\
\hline & S18 & 3.95 & 8.48 & S21 & 2.02 & 1.64 & S25 & N.A. & 2.44 \\
\hline \multirow{3}{*}{$\begin{array}{c}\text { D3 } \\
\text { (Pingjiang District) }\end{array}$} & S26 & 1.98 & 2.05 & S28 & 2.7 & 3.79 & S32 & 2.89 & 5.63 \\
\hline & S34 & 4.7 & 4.81 & S35 & 2.98 & 3.78 & S36 & 4.62 & 3.56 \\
\hline & S44 & 3.47 & 2.65 & S45 & 4.3 & N.A. & $\mathrm{S} 48$ & 3.31 & 2.98 \\
\hline \multirow{5}{*}{$\begin{array}{c}\text { D4 } \\
\text { (Wuzhong District) }\end{array}$} & S1 & 2.82 & 3.91 & S33 & 3.36 & 3.75 & S39 & 3.44 & 3.93 \\
\hline & S42 & 3.77 & 4.69 & S43 & 4.72 & 3.27 & S46 & 3.82 & 5.57 \\
\hline & S47 & 3.13 & 3.84 & S53 & 4.87 & 3 & S58 & 2.55 & 2.1 \\
\hline & S63 & 6.84 & 2.58 & S64 & 3 & 4.22 & S67 & 4.18 & 3.2 \\
\hline & S92 & 2.73 & 2.13 & S93 & 4.12 & 5 & S94 & 2.43 & 4.42 \\
\hline \multirow{2}{*}{$\begin{array}{c}\text { D5 } \\
\text { (Xiangcheng District) }\end{array}$} & S37 & 2.97 & 6.01 & S96 & 5.53 & 2.74 & S97 & 3.03 & 4.06 \\
\hline & S98 & 4.66 & 5.23 & S100 & 5.67 & 2.1 & & & \\
\hline \multirow{5}{*}{$\begin{array}{c}\text { D6 } \\
\text { (Huqiu District) }\end{array}$} & S2 & 4 & 4.27 & S3 & 3.07 & 3.83 & S4 & 3.79 & 2.5 \\
\hline & S5 & 3.34 & 4.01 & S6 & N.A. & 4.21 & S7 & 5.67 & 3.82 \\
\hline & S8 & 2.49 & 2.13 & S9 & 2.48 & 4.02 & S13 & 4.31 & 8.05 \\
\hline & S15 & 2.67 & 2.31 & S86 & 3.52 & 5.16 & S87 & 3.71 & 6.92 \\
\hline & S89 & 2.75 & 1.46 & S90 & 2.87 & 7.63 & S91 & 5.15 & 3.96 \\
\hline \multirow{9}{*}{$\begin{array}{c}\text { D7 } \\
\text { (Suzhou Industrial } \\
\text { Park District) }\end{array}$} & S49 & 2.49 & 5.75 & S50 & 2.89 & 5.07 & S55 & 4.25 & 2.57 \\
\hline & S56 & 3.16 & 6.42 & S59 & 4.85 & 4.78 & S60 & 3.45 & 3.31 \\
\hline & S61 & 4.36 & 5.16 & S62 & N.A. & 2.98 & S65 & 3.02 & 3.13 \\
\hline & S69 & 3.59 & 2.92 & S71 & 3.7 & 4.58 & S73 & 1.85 & 7.66 \\
\hline & S74 & 2.7 & 4.16 & S75 & 3.71 & 6.07 & S76 & 5.32 & 2.21 \\
\hline & S78 & 2.37 & 1.82 & S79 & 3.66 & 2.51 & S80 & N.A. & 1.7 \\
\hline & S82 & N.A. & 5.37 & S83 & 1.67 & 5.19 & S84 & N.A. & 2.84 \\
\hline & S85 & 4.12 & 4.22 & S101 & 2.41 & 6.94 & S102 & 4.97 & 6.25 \\
\hline & S103 & 3.92 & 3.7 & S104 & 3.39 & 4.65 & & & \\
\hline
\end{tabular}

N.A. Not available.

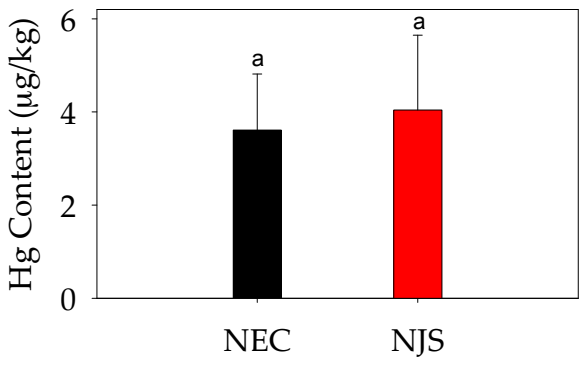

Rice from different production areas

(a)

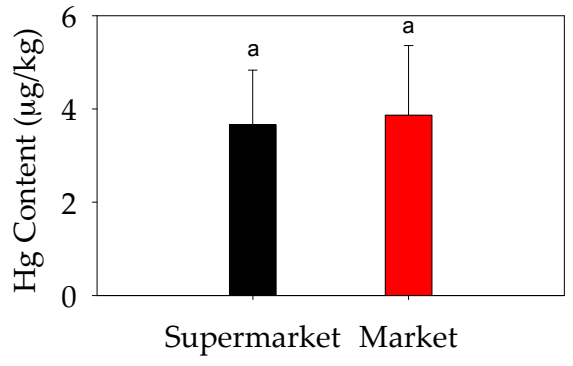

Rice from different sources

(b)

Figure 2. (a) Mercury content (mean \pm standard deviation) in rice from different production areas, northeastern China (NEC) and northern Jiangsu (NJS); (b) Mercury content (mean \pm standard deviation) in rice from different sources. Letter a in the figure indicate significant difference $(p<0.05)$. 


\subsection{Results of the Questionnaire Survey}

The results of the 236 completed questionnaires are summarized in Table 2. Among the respondents, $58.5 \%$ were male and $41.5 \%$ female. According to the recommendations of the $\mathrm{WHO}$, three age groups were defined in the present study: members of group I $(n=186)$ were 18-44 years old, those in group II $(n=40) 45-59$ years old, and those in group III $(n=10) 60-74$ years old. Rice was the staple food for $39 \%$, wheat for $11 \%$, and both for $50 \%$ of the respondents in Suzhou. The high percentage of Suzhou residents for whom rice is a staple food demonstrates the importance of assessing the risk of $\mathrm{Hg}$ exposure via rice in China. As determined in our preliminary study, markets $(42 \%)$ and supermarkets $(52 \%)$ were the major sites of rice purchase.

Table 2. Summary of the responses to the questionnaire survey in Suzhou city.

\begin{tabular}{cccccc}
\hline Sex & Male & Female & & & \\
& $58.5 \%$ & $41.5 \%$ & & & \\
\hline \multirow{2}{*}{ Age * } & Age $<30$ & $30 \leq$ Age $<40$ & $40 \leq$ Age $<50$ & $50 \leq$ Age & \\
& $44.1 \%$ & $27.1 \%$ & $13.1 \%$ & $15.7 \%$ & \\
\hline \multirow{2}{*}{ Staple Food * } & Rice & Wheat & Both & Other & \\
& $38.6 \%$ & $11.4 \%$ & $50.0 \%$ & $0.0 \%$ & \\
\hline \multirow{2}{*}{ Source * } & Supermarket & Market & Home & Canteen & Other \\
& $52.1 \% * *$ & $41.5 \% * *$ & $4.7 \% * *$ & $28.0 \% * *$ & $2.1 \%$ ** \\
\hline
\end{tabular}

${ }^{*}$ Data of both male and female responses combined; ${ }^{* *}$ Multiple choices were allowed.

The IR for respondents in Suzhou ranged from 0.05 to $0.4 \mathrm{~kg} /$ day. The average of $0.2 \mathrm{~kg} /$ day was comparable to that reported for Jiangsu residents $(0.21 \mathrm{~kg} /$ day, [33]). The IR of Suzhou residents was generally much higher than that of residents in northern provinces, where wheat rather than rice is preferentially consumed. For example, in Liaoning Province the annual IR is $54.4 \mathrm{~kg}$ (i.e., $149 \mathrm{~g} /$ day) [34]. According to a national survey, average rice consumption in northern China (e.g., $130.3 \mathrm{~g} /$ day in Heilongjiang Province, $118.3 \mathrm{~g} /$ day in Hebei Province, $53.9 \mathrm{~g} /$ day in Shanxi Province) is much less than southern China (e.g., 282.4 g/day in Fujian Province, 308.2 g/day in Sichuan Province, $260 \mathrm{~g} /$ day in Guangxi Province) [35]. In comparison, Americans consume 0.5 cup of cooked rice each day [36], that is about $28.3 \mathrm{~g} /$ day. Consumption of rice per capita for Bangladeshis in UK was $251 \mathrm{~g} /$ day, 30 times more than that of White Caucasians in UK [37]. Thus, it is evident that the IR for residents in Suzhou is a representative data for Asians, especially Southern Chinese.

The IRs for male and female respondents were $0.23 \pm 0.09$ and $0.16 \pm 0.09 \mathrm{~kg} /$ day, respectively. The difference was significant $(p<0.05)$ (Figure 3a) and in agreement with the rates reported elsewhere in China as well as other parts of the world. In Guangdong Province, average rice consumption by males is $10.1 \mathrm{~kg} / \mathrm{month}$, and that of females $8.8 \mathrm{~kg} / \mathrm{month}$ [38]. In a cadmium-polluted area in China, individuals ranging in age from 20 to 59 years had a sex-related difference in rice consumption. In our study herein, males consumed $449.6 \mathrm{~g}$ rice/day, and females $351.4 \mathrm{~g} /$ day [39]. Age had only minor effects on the IR $(p>0.05)$, averaging $0.2 \pm 0.09(0.05-0.4) \mathrm{kg} /$ day, $0.18 \pm 0.1(0.05-0.4) \mathrm{kg} / \mathrm{day}$, and $0.22 \pm 0.079(0.1-0.3) \mathrm{kg} /$ day for age groups I, II, and III, respectively (Figure 3b). This is consistent with rice being the staple food for people of different ages in eastern China. However, the result is based on questionnaires that excluded the underage group. It might be different if children were involved, as investigations showed that IR for adults is almost double (389.2 g/day vs. $198.4 \mathrm{~g} /$ day) [40] or even triple (324.4 g/day vs. $112.4 \mathrm{~g} /$ day) [41] that of children. 


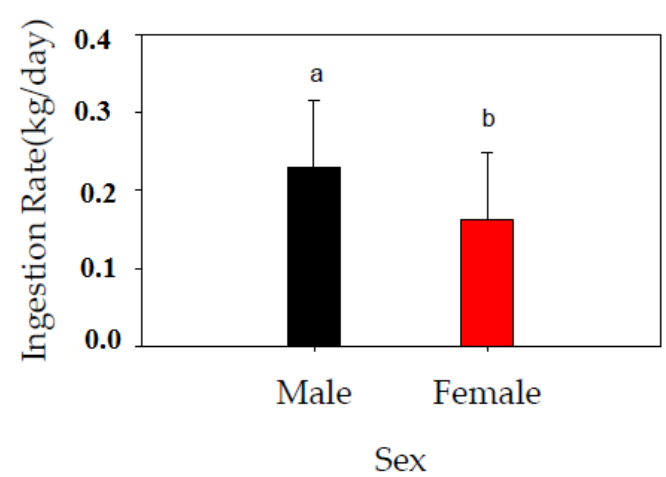

(a)

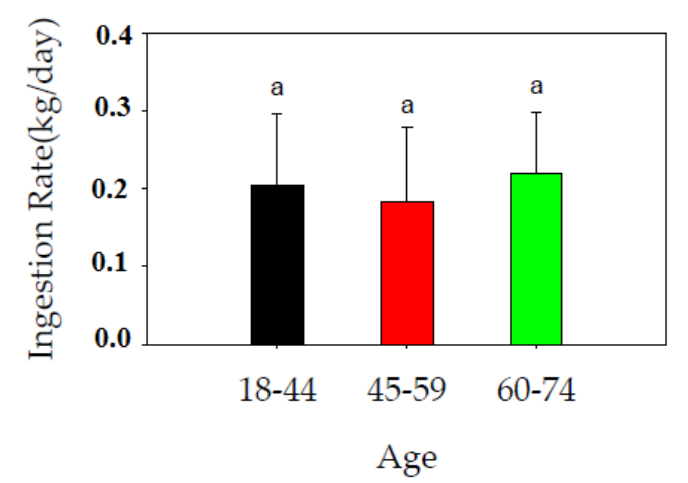

(b)

Figure 3. (a) Rice ingestion rates (mean \pm standard deviation) according to the sex of the study participants; (b) Rice ingestion rates (mean \pm standard deviation) according to the age of the study participants. Data of both male and female responses combined. Different letters $a, b$ in the figure indicate significant difference $(p<0.05)$.

\subsection{Risk Assessment of Hg in Rice for Suzhou Residents}

The HQ, as obtained in the present study, ranged from 0.005 to 0.05 (mean of 0.02 ) and indicated a generally low risk of $\mathrm{Hg}$ exposure via rice consumption by Suzhou residents. Compared to the $\mathrm{HQ}$ related to fish consumption, the $\mathrm{HQ}$ of a health risk for Chinese residents due to $\mathrm{Hg}$ in rice has been less well documented. Rather, most studies have examined the risk posed by fish even though rice is the major source of dietary $\mathrm{Hg}$ exposure. Nonetheless, a comparison of our results with the limited number of HQ values reported in the literatures indicated that the HQ values in Suzhou were comparable to or lower than those reported from other non-contaminated areas of China. For example, the HQs of Zhejiang Province and Changshu city residents were 0.042 and 0.143 , respectively [22,42]. By contrast, the values for Suzhou residents were lower than those documented for residents of $\mathrm{Hg}$-contaminated areas in China. For example, in a zinc-lead mining area located in Hunan Province, the HQ was 0.70 [43], and for residents living near a mercury mine in Guizhou Province it was 1.7. In those studies, the $\mathrm{Hg}$ content in rice from the contaminated area in Hunan Province was $0.07 \mathrm{mg} / \mathrm{kg}$ and the IR was $0.43 \mathrm{~kg} /$ day, much higher than the corresponding values in our study. For residents of Guizhou Province, the IR was $0.39 \mathrm{~kg} /$ day; that study also reported a MeHg content in hair of 0.13 $\mathrm{mg} / \mathrm{kg}$. The results provide evidence of the potential health threat of $\mathrm{Hg}$-contaminated rice [44] and the need to take into account both the IR and $\mathrm{Hg}$ content.

In the present study, the health risk related to $\mathrm{Hg}$-contaminated rice was compared in the participants with respect to health and age. For age groups I, II and III, the HQ values were 0.022, 0.020 and 0.023 , respectively; the differences were not significant $(p>0.05)$ (Figure $4 a)$. This could be attributed to the less variable IR for consumers in different age groups. Similarly, comparable HQ values were found for male and female residents of Suzhou $(p>0.05)$, despite the higher IR for males (Figure $4 \mathrm{~b}$ ). This was mainly because of the generally lower body weight of female than male consumers. In addition, neither the place of purchase (98 markets vs. 123 supermarkets) nor the source of the rice ( $87 \mathrm{NEC}, 90 \mathrm{NJS}$ ) significantly affected the HQ of $\mathrm{Hg}$ in rice. This observation can be explained by the comparable levels of $\mathrm{Hg}$ in rice among these categories. Although no significant differences between sexes was observed herein, there is a case [45] suggesting that women have a longer half-time of $\mathrm{Hg}$ in kidneys than men. This difference may lead to different risks for the two populations, which cannot be ignored and needs to be further examined. In contrast to HQ related to rice consumption, HQ related to fish consumption varies greatly between individuals as a result of their different habit or frequency of fish consumption. For instance, people who live near the sea eat fish more frequently and thus their HQ related to fish consumption was much higher than those far away from the sea [46]. For some particular individuals such as fishermen, HQ related to fish 
consumption is almost 3 times higher than that from rice (74\%:23\%) [47]. This is not only due to the higher content of $\mathrm{Hg}$ in fish but also because of the higher proportion of $\mathrm{MeHg}$ in fish (97.6\%) as compared to rice (87.1\%) [46]. However, it should be noted that differences in beneficial constituents in rice and fish should also be considered when comparing risks of $\mathrm{Hg}$ associated with rice and fish consumption. For instance, relatively high levels of long-chain omega-3 fatty acids were commonly found in fish, which may partly counteract the toxic effects of $\mathrm{Hg}$ in fish [48-50]. Therefore, the same dosage of $\mathrm{Hg}$ in fish and rice may not result in the same risk for human consumption, which should be considered in future studies.

Based on risk calculation, consumption advisory for Suzhou residents was provided (Figure 5): Threshold level of consumption rate for Suzhou residents is $8.98 \mathrm{~kg}$ per day for people with an average bodyweight of $60 \mathrm{~kg}$, when $\mathrm{Hg}$ concentration in rice is at the average level (averagely $3.82 \mathrm{ng} / \mathrm{g}$ in this study). Considering the documented daily consumption rate of rice ( $0.21 \mathrm{~kg}$ per day for Suzhou residents [33]), our results may clearly suggest that risk of $\mathrm{Hg}$ associated with rice consumption is generally low for consumers in Suzhou city.

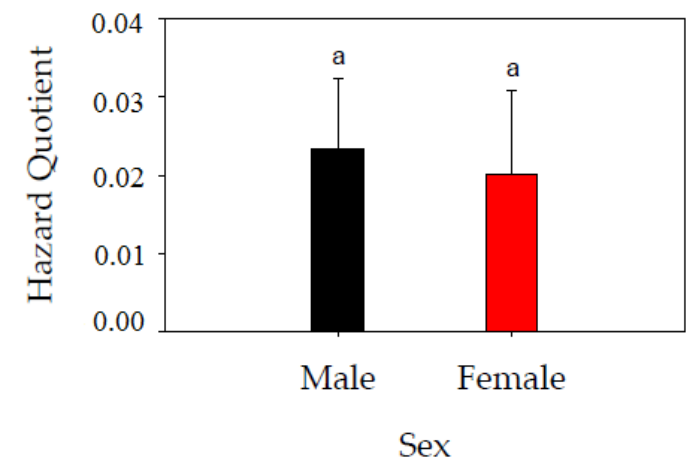

(a)

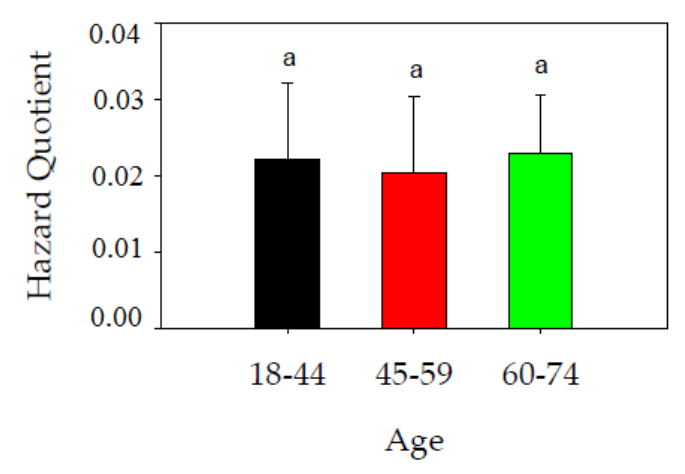

(b)

Figure 4. (a) Estimated risks (mean \pm standard deviation) of $\mathrm{Hg}$ exposure in rice with respect to the sex of consumers; (b) Estimated risks (mean \pm standard deviation) of $\mathrm{Hg}$ exposure in rice with respect to age of consumers. Data of both male and female responses combined. Letter a in the figure indicate significant difference $(p<0.05)$.

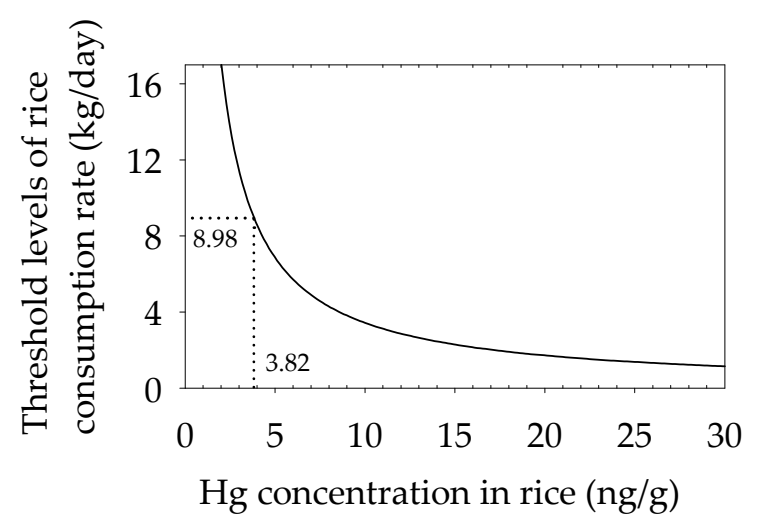

Figure 5. Threshold levels of consumption rate in accordance with the $\mathrm{Hg}$ concentration in rice.

\section{Conclusions}

The results of the present study clearly demonstrated the low risk of $\mathrm{Hg}$ exposure associated with rice consumption by consumers in Suzhou city and may be representative of other cities in eastern China. Neither the place of purchase nor the source of the rice, nor the sex and age of consumers was associated with a health risk posed by the potential $\mathrm{Hg}$ contamination of rice. Future studies should 
compare the Hg levels in rice and fish, the two major sources of dietary $\mathrm{Hg}$ exposure in China, and their effects on human health. The findings will contribute to a better understanding of the risk of $\mathrm{Hg}$ in food for the general population in other non-contaminated areas of China.

Acknowledgments: We are grateful for the valuable comments from the anonymous reviewers on this work. This work was financially supported by grants from the National Natural Science Foundation of China (41673075) to Huan Zhong. This work was also sponsored by the Major Science and Technology Program for Water Pollution Control and Treatment of China (No. 2012ZX07101-005).

Author Contributions: Conceived and designed the study: Huan Zhong and Liu-Yan Yang; Analyzed the data: Yu Gong; Supported the technique: Yi-Xin Zhu; Performed the experiment and wrote the paper: Gang Wang; Revised the paper: Ai-Jun Miao; All authors have read and approved the final manuscript.

Conflicts of Interest: The authors declare no conflict of interest.

\section{References}

1. Rice, G.; Swartout, J.; Mahaffey, K.; Schoeny, R. Derivation of U.S. EPA's oral reference dose (rfd) for methylmercury. Drug Chem. Toxicol. 2000, 23, 41-54. [CrossRef] [PubMed]

2. National Research Council Committee on the Toxicological Effects. Toxicological Effects of Methylmercury; National Academies Press: Washington, DC, USA, 2000.

3. Mergler, D.; Anderson, H.A.; Chan, L.H.M.; Mahaffey, K.R.; Murray, M.; Sakamoto, M.; Stern, A.H. Methylmercury exposure and health effects in humans: A worldwide concern. Ambio 2007, 36, 3-11. [CrossRef]

4. Gueguen, M.; Amiard, J.C.; Arnich, N.; Badot, P.M.; Claisse, D.; Guerin, T.; Vernoux, J.P. Shellfish and residual chemical contaminants: Hazards, monitoring, and health risk assessment along French coasts. In Reviews of Environmental Contamination and Toxicology; Whitacre, D.M., Ed.; Springer: New York, NY, USA, 2011; Volume 213, pp. 55-111.

5. Peng, Q.; Nunes, L.M.; Greenfield, B.K.; Dang, F.; Zhong, H. Are chinese consumers at risk due to exposure to metals in crayfish? A bioaccessibility-adjusted probabilistic risk assessment. Environ. Int. 2016, 88, 261-268. [CrossRef] [PubMed]

6. Liu, J.L.; Xu, X.R.; Yu, S.; Cheng, H.; Peng, J.X.; Hong, Y.G.; Feng, X.B. Mercury contamination in fish and human hair from Hainan island, south China sea: Implication for human exposure. Environ. Res. 2014, 135, 42-47. [CrossRef] [PubMed]

7. Chan, H.M.; Scheuhammer, A.M.; Ferran, A.; Loupelle, C.; Holloway, J.; Weech, S. Impacts of mercury on freshwater fish-eating wildlife and humans. Hum. Ecol. Risk Assess. 2003, 9, 867-883. [CrossRef]

8. Dorea, J.G. Persistent, bioaccumulative and toxic substances in fish: Human health considerations. Sci. Total Environ. 2008, 400, 93-114. [CrossRef] [PubMed]

9. Li, J.; Huang, Z.Y.; Hu, Y.; Yang, H. Potential risk assessment of heavy metals by consuming shellfish collected from Xiamen, China. Environ. Sci. Pollut. Res. 2013, 20, 2937-2947. [CrossRef] [PubMed]

10. Virtanen, J.K.; Rissanen, T.H.; Voutilainen, S.; Tuomainen, T.-P. Mercury as a risk factor for cardiovascular diseases. J. Nutr. Biochem. 2007, 18, 75-85. [CrossRef] [PubMed]

11. Grump, K.S.; Kjellström, T.; Shipp, A.M.; Silvers, A.; Stewart, A. Influence of prenatal mercury exposure upon scholastic and psychologica test performance: Benchmark analysis of a New Zealand cohort. Risk Anal. 1998, 18, 701-713. [CrossRef]

12. Myers, G.J.; Davidson, P.W.; Cox, C.; Shamlaye, C.F.; Palumbo, D.; Cernichiari, E.; Sloane-Reeves, J.; Wilding, G.E.; Kost, J.; Huang, L.S.; et al. Prenatal methylmercury exposure from ocean fish consumption in the seychelles child development study. Lancet 2003, 361, 1686-1692. [CrossRef]

13. Zhang, H.; Feng, X.; Larssen, T.; Shang, L.; Li, P. Bioaccumulation of methylmercury versus inorganic mercury in rice (Oryza sativa L.) grain. Environ. Sci. Technol. 2010, 44, 4499-4504. [CrossRef] [PubMed]

14. Qiu, G.; Feng, X.; Meng, B.; Wang, X. Methylmercury in rice (Oryza sativa L.) grown from the Xunyang Hg mining area, Shanxi province, northwestern China. Pure Appl. Chem. 2012, 84, 281-289.

15. Zhang, H.; Feng, X.; Larssen, T.; Qiu, G.; Vogt, R.D. In inland China, rice, rather than fish, is the major pathway for methylmercury exposure. Environ. Health Perspect. 2010, 118, 1183-1188. [CrossRef] [PubMed] 
16. Windham-Myers, L.; Fleck, J.A.; Ackerman, J.T.; Marvin-DiPasquale, M.; Stricker, C.A.; Heim, W.A.; Bachand, P.A.M.; Eagles-Smith, C.A.; Gill, G.; Stephenson, M.; et al. Mercury cycling in agricultural and managed wetlands: A synthesis of methylmercury production, hydrologic export, and bioaccumulation from an integrated field study. Sci. Total Environ. 2014, 484, 221-231. [CrossRef] [PubMed]

17. Li, P.; Du, B.Y.; Chan, H.M.; Feng, X.B. Human inorganic mercury exposure, renal effects and possible pathways in Wanshan mercury mining area, China. Environ. Res. 2015, 140, 198-204. [CrossRef] [PubMed]

18. Strickman, R.J.; Mitchell, C.R.J. Accumulation and translocation of methylmercury and inorganic mercury in oryza sativa: An enriched isotope tracer study. Sci. Total Environ. 2017, 574, 1415-1423. [CrossRef] [PubMed]

19. Feng, X.; Li, P.; Qiu, G.; Wang, S.; Li, G.; Shang, L.; Meng, B.; Jiang, H.; Bai, W.; Li, Z.; et al. Human exposure to methylmercury through rice intake in mercury mining areas, Guizhou province, China. Environ. Sci. Technol. 2008, 42, 326-332. [CrossRef] [PubMed]

20. Karagas, M.R.; Choi, A.L.; Oken, E.; Horvat, M.; Schoeny, R.; Kamai, E.; Cowell, W.; Grandjean, P.; Korrick, S. Evidence on the human health effects of low-level methylmercury exposure. Environ. Health Perspect. 2012, 120, 799-806. [CrossRef] [PubMed]

21. Zahir, F.; Rizwi, S.J.; Haq, S.K.; Khan, R.H. Low dose mercury toxicity and human health. Environ. Toxicol. Pharmacol. 2005, 20, 351-360. [CrossRef] [PubMed]

22. Huang, Z.; Pan, X.D.; Wu, P.G.; Han, J.L.; Chen, Q. Health risk assessment of heavy metals in rice to the population in Zhejiang, China. PLoS ONE 2013, 8, e75007. [CrossRef] [PubMed]

23. Boffetta, P.; Merler, E.; Vainio, H. Carcinogenicity of mercury and mercury-compounds. Scand. J. Work Environ. Health 1993, 19, 1-7. [CrossRef] [PubMed]

24. U.S. Environmental Protection Agency. Risk Assessment Guidance for Superfund Volume 1 Human Health Evaluation Manual (Part A): Interim Final; USEPA: Washington, DC, USA, 1991.

25. Ministry of Public Health of China. GB 2762-2012 China National Food Safety Standard: Maximum Limit of Contaminants in Food. Available online: http://www.nhfpc.gov.cn/ewebeditor/uploadfile/2013/01/ 20130128114248937.pdf (accessed on 1 April 2017).

26. Brombach, C.C.; Manorut, P.; Kolambage-Dona, P.P.P.; Ezzeldin, M.F.; Chen, B.; Corns, W.T.; Feldmann, J.; Krupp, E.M. Methylmercury varies more than one order of magnitude in commercial European rice. Food Chem. 2017, 214, 360-365. [CrossRef] [PubMed]

27. Eom, Y.; Kim, D.-Y.; Han, S.H.; Lee, T.G. Preparation of quality control materials for the determination of mercury in rice. Food Chem. 2014, 147, 361-366. [CrossRef] [PubMed]

28. Shi, J.B.; Meng, M.; Shao, J.J.; Zhang, K.G.; Zhang, Q.H.; Jiang, G.B. Spatial distribution of mercury in topsoil from five regions of China. Environ. Sci. Pollut. Res. 2013, 20, 1756-1761. [CrossRef] [PubMed]

29. Cui, J.; Zang, S.; Zhai, D.; Wu, B. Potential ecological risk of heavy metals and metalloid in the sediments of Wuyuer river basin, Heilongjiang province, China. Ecotoxicology 2014, 23, 589-600. [CrossRef] [PubMed]

30. Wang, L.; Yan, B.; Zhu, L.; Ou, Y. The effect of reclamation on the distribution of heavy metals in saline-sodic soil of Songnen plain, China. Environ. Earth Sci. 2015, 73, 1083-1090. [CrossRef]

31. Ministry of Environmental Protection of China. Environmental Quality Standards for Soils. Available online: http:/ / kjs.mep.gov.cn/hjbhbz/bzwb/trhj/trhjzlbz/199603/W020070313485587994018.pdf (accessed on 1 April 2017).

32. Rothenberg, S.E.; Feng, X.; Zhou, W.; Tu, M.; Jin, B.; You, J. Environment and genotype controls on mercury accumulation in rice (Oryza sativa L.) cultivated along a contamination gradient in Guizhou, China. Sci. Total Environ. 2012, 426, 272-280. [CrossRef] [PubMed]

33. Jiangsu Statistics Bureau. Jiangsu Statistical Yearbook; China Statistics Press: Beijing, China, 2016; Volume 5.

34. Liaoning Statistics Bureau. Liaoning Statistical Yearbook; China Statistics Press: Beijing, China, 2016; Volume 10.

35. Wu, Y.; Li, X. The Fourth China Total Diet Study; Chemical Industry Press: Beijing, China, 2015.

36. Gilbert-Diamond, D.; Cottingham, K.L.; Gruber, J.F.; Punshon, T.; Sayarath, V.; Gandolfi, A.J.; Baker, E.R.; Jackson, B.P.; Folt, C.L.; Karagas, M.R. Rice consumption contributes to arsenic exposure in US women. Proc. Natl. Acad. Sci. USA 2011, 108, 20656-20660. [CrossRef] [PubMed]

37. Cascio, C.; Raab, A.; Jenkins, R.O.; Feldmann, J.; Meharg, A.A.; Haris, P.I. The impact of a rice based diet on urinary arsenic. J. Environ. Monit. 2011, 13, 257-265. [CrossRef] [PubMed]

38. Zhou, S.; Deng, X.; Liang, H.; Hu, S.; Wen, J.; Huang, W.; Lin, X.; Wang, P.; Liu, C.; Yang, X. Cadmium contamination and dietary exposure assessment in retailed rice in Guangdong province, 2012. South China J. Prev. Med. 2013, 139, 4-9. 
39. Han, X.; Zhang, W.; Shang, Q. Comparison of two methods in calculating the cumulative cadmium intake (CCI) from rice in the cadmium polluted area. J. Hyg. Res. 2015, 44, 939-942, 969.

40. Zheng, N.; Wang, Q.; Zhang, X.; Zheng, D.; Zhang, Z.; Zhang, S. Population health risk due to dietary intake of heavy metals in the industrial area of Huludao city, China. Sci. Total Environ. 2007, 387, 96-104. [CrossRef] [PubMed]

41. Zhang, L.E.; Mo, Z.; Qin, J.; Li, Q.; Wei, Y.; Ma, S.; Xiong, Y.; Liang, G.; Qing, L.; Chen, Z.; et al. Change of water sources reduces health risks from heavy metals via ingestion of water, soil, and rice in a riverine area, south China. Sci. Total Environ. 2015, 530-531, 163-170. [CrossRef] [PubMed]

42. Hang, X.; Wang, H.; Zhou, J.; Ma, C.; Du, C.; Chen, X. Risk assessment of potentially toxic element pollution in soils and rice (Oryza sativa) in a typical area of the Yangtze river delta. Environ. Pollut. 2009, 157, 2542-2549. [CrossRef] [PubMed]

43. Lu, S.; Wang, Y.; Teng, Y.; Yu, X. Heavy metal pollution and ecological risk assessment of the paddy soils near a zinc-lead mining area in Hunan. Environ. Monit. Assess. 2015, 187, 627. [CrossRef] [PubMed]

44. Li, W.C.; Ouyang, Y.; Ye, Z.H. Accumulation of mercury and cadmium in rice from paddy soil near a mercury mine. Environ. Toxicol. Chem. 2014, 33, 2438-2447. [CrossRef] [PubMed]

45. Akerstrom, M.; Barregard, L.; Lundh, T.; Sallsten, G. Relationship between mercury in kidney, blood, and urine in environmentally exposed individuals, and implications for biomonitoring. Toxicol. Appl. Pharmacol. 2017, 320, 17-25. [CrossRef] [PubMed]

46. Tang, W.; Cheng, J.; Zhao, W.; Wang, W. Mercury levels and estimated total daily intakes for children and adults from an electronic waste recycling area in Taizhou, China: Key role of rice and fish consumption. J. Environ. Sci. 2015, 34, 107-115. [CrossRef] [PubMed]

47. Shao, D.; Kang, Y.; Cheng, Z.; Wang, H.; Huang, M.; Wu, S.; Chen, K.; Wong, M.H. Hair mercury levels and food consumption in residents from the Pearl river delta: South China. Food Chem. 2013, 136, 682-688. [CrossRef] [PubMed]

48. Myers, G.J.; Davidson, P.W.; Strain, J.J. Nutrient and methyl mercury exposure from consuming fish. J. Nutr. 2007, 137, 2805-2808. [PubMed]

49. Mahaffey, K.R.; Sunderland, E.M.; Chan, H.M.; Choi, A.L.; Grandjean, P.; Marien, K.; Oken, E.; Sakamoto, M.; Schoeny, R.; Weihe, P.; et al. Balancing the benefits of n-3 polyunsaturated fatty acids and the risks of methylmercury exposure from fish consumption. Nutr. Rev. 2011, 69, 493-508. [CrossRef] [PubMed]

50. Mahaffey, K.R. Fish and shellfish as dietary sources of methylmercury and the omega-3 fatty acids, eicosahexaenoic acid and docosahexaenoic acid: Risks and benefits. Environ. Res. 2004, 95, 414-428. [CrossRef] [PubMed]

(C) 2017 by the authors. Licensee MDPI, Basel, Switzerland. This article is an open access article distributed under the terms and conditions of the Creative Commons Attribution (CC BY) license (http:/ / creativecommons.org/licenses/by/4.0/). 